\title{
ANALISIS MARGIN LABA BERSIH TERHADAP PENCAPAIAN PENINGKATAN LABA ATAS PENDAPATAN YANG DIPEROLEH PADA USAHA LAUNDRY (STUDI KASUS USAHA DI MAKASSAR)
}

\author{
SATRIANI \\ MUFTI KHAERIAH B. \\ WAHYU MARDIASTUTI \\ HASANUDDIN \\ MUHAMMAD AKBAR \\ Universitas Muhammadiyah Makassar, Jl. Sultan Alauddin No.259, Kota Makassar, Sulawesi Selatan, Indonesia \\ Anisatriani662@gmail.com

\begin{abstract}
Net Profit Margin or NPM is the ratio to find out the profit obtained from net sales by companies or small businesses by comparing net income and net sales. The purpose of this research is to analyze the Net Profit Margin in the Laundry business 57 in 2019 Makassar city. This research uses descriptive quantitative research methods. The results of this study indicate that the Net Profit Margin or NPM laundry 57 in 2019 is very good, namely in the range of $69.10 \%-81.22 \%$. In January to June, there was an increase and decrease in the Net Profit Margin ratio, namely the percentage of $72.9 \%, 69.10 \%, 75.8 \%, 74.10 \%, 81,22 \%$ and $80.6 \%$. In July and August, it decreased with the same percentage of the NPM ratio, namely $71.5 \%$. And NPM in September to December 2019 has increased continuously with the NPM ratio, namely: $72.2 \%, 73.1 \%, 74.8 \%$, and $81.2 \%$.
\end{abstract}

Keywords: Net profit margin, ratio analysis, earnings, laundry

Abstrak: Margin Laba Bersih atau NPM adalah rasio untuk mengetahui keuntungan yang diperoleh dari penjualan bersih oleh perusahaan atau usaha kecil dengan membandingkan laba bersih dan penjualan bersih. Tujuan penelitian ini adalah untuk menganalisis Net Profit Margin pada usaha Laundry 57 tahun 2019 kota Makassar. Penelitian ini meggunakan metode penelitian kuantitatif deskriptif. Hasil penelitian ini menunjukkan bahwa Margin Laba Bersih atau NPM laundry 57 pada tahun 2019 sangat baik yaitu berkisaran 69,10\%-81,22\%. Pada bulan januari hingga juni mengalami kenaikkan dan penurunan pada rasio Margin Laba Bersih yaitu dengan persentase $72,9 \%, 69,10 \%, 75,8 \%, 74,10 \%, 81,22 \%$ dan $80,6 \%$. Pada bulan juli dan bulan agustus mengalami penurunan dengan persentase rasio NPM yang sama yaitu sebesar $71,5 \%$. Dan NPM pada bulan september hingga bulan desember tahun 2019 mengalami kenaikan terus-menerus dengan besaran rasio NPM yaitu: $72,2 \%, 73,1 \%, 74,8 \%$, dan $81,2 \%$.

Kata Kunci: Margin laba bersih, analisis rasio, laba, laundry 


\section{PENDAHULUAN}

Dengan perkembangan zaman saat ini, banyak sekali orang yang sibuk atas pekerjaannya atau dengan kegiatan lainnya terutama pada perempuan saat ini yang banyak mengejar karirnya, mengurus rumah tangga sambil berkarir. Sehingga jarang sekali menyempatkan waktu untuk memperhatikan pekerjaan rumah, memperhatikan cucian pakaiannya dan menyetrika. Hal ini disebabkan semakin canggihnya teknologi dan semakin meningkatnya pendidikan saat ini dan menyebabkan menurunya minat karir sebagai asisten rumah tangga dan meningkatnya karir di perkantoran atau pun buruh pabrik. Sehingga dengan adanya kondisi saat ini, membuka peluang bagi usaha Laundry.

Usaha Laundry merupakan salah satu bentuk usaha yang bergerak di bidang jasa, memberikan jasa cuci, melipat dan menyetrika. Dengan adanya jasa laundry ini, membantu para pekerja yang jarang meluangkan waktunya untuk memperhatikan cuciannya. Sehingga jasa laundry dapat memberikan jasa cuci, lipat dan menyetrika. Seperti laundry yang berada di kota makassar yang bernama laundry 57 , konsumen pada laundry 57 bukan hanya pekerja kantoran saja melainkan mahasiswa dan hotel. Usaha ini juga berkembang pesat sehingga banyak saingan, beberapa macam bentuk usaha untuk memenangkan persaingan dengan cara meneberikan potongan, antar jemput, bahkan adanya usaha laundry yang memberikan free harga pada jenis cucian seperti perangkat alat sholat.

Harga jual pada usaha laundry kebanyakan mengikuti harga pasar, tanpa menghitung terlebih dahulu biaya yang dikeluarkan dan laba yang dihasilkan dalam usaha tersebut. Karena laba adalah pendapatan yang menjadi tolak ukur usaha ke depannya, tujuan dari membuka usaha adalah untuk menghasilkan laba (profit). (Tompodung, 2014) menyatakan bahwa mengukur suatu efisiensi aktivitas perusahaan dalam kemampuan memperoleh keuntungan dapat di ukur dengan Ratio Net Profit Margin yaitu kemampuan dalam memperoleh laba melalui sumber yang ada seperti penjualan, kas, modal, dan sebagainya, salah satunya yaitu rasio margin laba.

Hery (2016:98) berpendapat bahwa margin laba bersih merupakan rasio yang digunakan untuk mengukur besarnya persentase laba bersih atas penjualan bersih. Dalam membuka usaha harus mengetahui besarnya pendapatan, biaya, dan laba dari usaha yang dibangun. Untuk mengetahui laba bersih dalam usaha jasa laundry ini dilihat harga pokok penjualannya, hpp usaha jasa ini merupakan berapa jumlah pengeluaran biaya dalam menghasilkan suatu jasa agar tidak mengalami kerugian dalam membuka usaha. Banyak pelaku usaha yang salah dalam menetukan harga jual disebabkan si pelaku tidak memperhitungkan hppnya melainkan hanya mengikuti harga pasar bahkan menjual dengan harga murah untuk memenangkan persaingan dan tidak mengetahui kondisi usaha yang dijalankan apakah mengalami kerugian atau keuntungan. Berdasarkan uraian diatas, maka peneliti termotivasi untuk meneliti Net Profit Margin pada usaha laundry yang sedang berkembang saat ini. Penelitian ini bertujuan untuk menganalisis Margin Laba Bersih (Net Profit Margin) Pada Usaha Laundry 57 Di Kota Makassar.

\section{Teori Sinyal}

Signaling Theory (Teori Sinyal) merupakan teori yang menyatakan adanya dorongan yang dimiliki oleh pemilik usaha berdasarkan atas informasi yang diperoleh mengenai usaha yang dijalankan. Sehingga pemilik usaha akan terdorong untuk meningkatkan perkembangan usaha yanng dijalankan melalui sinyal informasi yang diperoleh. Pada penelitian ini singnaling theory (teori sinyal) yang menyatakan bahwa 
perolehan informasi atas perhitungan margin laba bersih dapat memberikan sinyal kepada pemilik usaha agar dapat meningkatkan usahanya lagi serta dalam perhitungan NPM ini memberikan informasi keuntungan atau laba yang diperoleh pemilik usaha atas penjualannya. Dalam hal ini NPM yang menjadi tolak ukur untuk menilai tingkat kesuksesan usaha dan memberikan sinyal informasi kepada pemilik usaha berdasarkan hasil informasi mengenai keuntungan yang diperoleh dari perhitungan NPM untuk meningkatkan laba atas pendapatan yang diperoleh usaha ke priode berikutnya dan menghindari dari kerugian pada usaha yang dijalankan.

Sinyal ini berupa informasi menyangkut tentang apa yang telah dilakukan oleh pemilik usaha dengan kegiatan operasi dalam menjalankan usahanya untuk mencapai tujuan di bangunnya usaha yaitu mencapai keuntungan atau laba. Apa bila hasil dari perhitungan NPM memperoleh persentase lebih dari 10\%, maka informasi ini memberikan sinyal yang baik bagi pemilik usaha atas usaha yang dijalankan sedangkan apabila hasil dari perhitungan NPM memperoleh persentase kurang dari $10 \%$, maka hal ini memberikan sinyal buruk bagi pemilik usaha atas usaha yang dijalannkan dan harus lebih memperhatikan lagi dari segi kegiatan operasionalnya dalam menjalankan usahanya.

\section{Laporan Keuangan}

Prihadi (2019:103) menyatakan laporan keuangan adalah hasil dari kegiatan pencatatan seluruh transaksi keuangan di perusahaan. Transaksi keuangan adalah segala macam kegiatan yang dapat mempengaruhi kondisi keuangan perusahaan, seperti penjualan dan pembelian. Prihadi (2013: 29) laporan keuangan juga dapat digunakan sebagai proses untuk perencanaan atau analisis ke depan. Analisis ke depan merupakan sebagai analisis prospektif, proses penyusunan laporan keuangan memerlukan adanya penyederhanaan format laporan keuangan. Prihadi (2013: 32) Proses proyeksi dimulai dengan adanya model proyeksi. Secara umum model akan dibagi ke dalam tiga bagian utama, yaitu Masukan, Proses, dan Keluaran

\section{Tujuan Laporan Keuangan}

Lubis, Hidayat Rahmat (2017: 23) menyatakan bahwa secara umum, tujuan laporan keuangan adalah menyediakan informasi tentang proses keuangan, kinerja keuangan, dan laporan arus kas suatu entitas yang bermanfaat bagi pengguna laporan keuangan untuk pengambilan keputusan ekonomi sebagai kebutuhan informasi yang diperlukan. Dalam manajemen, laporan keuangan ini bertujuan untuk pertanggungjawaban manajemen atas kinerja yang dilakukan berdasarkan kepercayaan yang diberikan kepadanya. Ada beberapa tujuan penyajian dari sebuah laporan keuangan bagi suatu entitas yaitu:

1. Untuk memberikan informasi keuangan, kewajiban serta modal perusahaan yang dapat dipercaya oleh publik.

2. Untuk memberikan informasi tentang perubahan sumber ekonomi yang timbul dalam aktivitas usaha demi memperoleh laba perusahaan.

3. Untuk memeberikan informasi keuangan untuk membantu para pemakai laporan guna mengestimasi potensi perusahaan dalam menghasilkan laba dimasa depan.

4. Untuk memberikan informasi laporan keuangan kepada para pemakai laopan guna untuk mengestimasi potensi perusahaan dalam memperoleh laba

5. Untuk memeberikan informasi penting lainnya mengenai perubahan sumbersumber ekonomi dan kewajiban, seperti informasi tentang aktivitas pembiayan dan investasi. 
6. Untuk memberikan informasi lain yang akurat kepada yang membutuhkan laporan keuangan, seperti informasi mengenai kebijakan akuntansi perusahaan.

\section{Net Profit Margin atau Margin Laba Bersih}

Hery (2016:98) margin laba bersih merupakan rasio yang digunakan untuk mengukur besarnya persentase laba bersih atas penjualan bersih. Rasio ini dihitung dengan membagi laba bersih terhadap penjualan bersih. Untuk menentukan laba bersih dapat dihasilkan dengan cara laba sebelum pajak penghasilan dikurang dengan beban pajak penghasilan. Laba sebelum pajak penghasilan dapat dihitung dengan cara laba operasional ditambah dengan pendapatan dan keuntungan lainnya, lalu dikurangi dengan beban dan kerugian lainnya pada perusahaan.

Apabila suatu perusahaan memperoleh Margin Laba Bersih atau Net Profit Margin dengan jumlah persentase yang tinggi, maka laba bersih yang dihasilkan dari penjualan bersih dari suatu perusahaan tinggi. Hal ini disebabkan karena tingginya laba sebelumpajak penghasilan dari suatu perusahaan tersebut. Begitupun sebaliknya, apabila suatu perusahaan memperoleh Margin Laba Bersih atau Net Profit Margin dengan jumlah persentase yang rendah, maka laba bersih yang dihasilkan dari penjualan bersih dari suatu perusahaan juga rendah. Hal ini disebabkan karena rendahnya laba sebelumpajak penghasilan dari suatu perusahaan tersebut.

Sugiono dan Untung (2016:67) Net Profit Margin / Retun On Sales (Ros) merupakan rasio ini menunjukkan berapa besar keuntungan bersih yang diperoleh perusahaan. Jika profit margin suatu perusahaan lebih rendah daro rata-rata industrinya, maka hal ini dapat disebabkan oleh harga jual perusahaan lebih rendah dari pada perusahaan pesaing, ataupun kedua-duanya. Apabila perusahaan memiliki rasio NPM 3,33\% artinya dalam Rp.1 atas penjualan, suatu perusaan atau uasaha kecil tersebut dapat memperoleh Rp. 0,33 laba bersih.

Dari beberapa pengertian diatas, maka dapat ditarik kesimpulan bahwa Net Profit Margin (NPM) adalah rasio yang dapat digunakan untuk mengetahui seberapa besar keuntungan yang diperoleh dari penjualan bersih suatu perusahaan atau usaha-usaha kecil dapat dihitung dengan cara laba bersih dibagi dengan penjualan bersih. Bila suatu perusahaan memiliki besaran persentase Margin Laba Bersih atau Net Profit Margin (NPM) lebih dari 10\%, maka sudah dianggap sangat baik.

\section{Analisis Rasio}

Kioso et al. (2018:716) Dalam menganalisis data laporan keuangan, analisis menggunakan berbagai perangkat untuk mengetahui komparatif dan signifikansi informasi keuangan yang disajikan. Perangkat ini meliputi analisis ratio, analisis komparatif, analisis persentase, dan pengujian data terkait. Pada analisis hanya memperoleh jawaban yang dibutuhkan berdasarkan pengujian akan berkaitan antar semua data yang diberikan. Menganalisis rasio merupakan suatu titik awal. Salah satu jenis rasio utama yaitu rasio profitabilitas merupakan mengukur tingkat keberhasilan atau kegagalan yang diberikan perusahaan atau divisi untuk jangka waktu tertentu, yang merupakan rasio profitabilitas yaitu: Net Profit Margin( NPM), Operating Profit Margin (OPM) atau Return On Sales (ROS), Gross Profit Margin (GPM), Retun On Assets (ROA), dan Return On Equity (ROE).

\section{Batasan Analisis Rasio}

Kioso et al (2018:718) Salah satu batasan penting rasio adalah bahwa pada umumnya didasarkan pada biaya historis, yang dapat menyebabkan distorsi dalam mengukur kinerja. Penilaian yang tidak akurat atas kondisi 
keuangan dan kinerja perusahaan dapat mengakibatkan kegagalan dalam memasukan informasi nilai wajar perusahaan. Kemungkinan batasan analisis rasio yang paling besar adalah masalah yang paling sulit mencapai komparabilitas antar perusahaan dalam industri tertentu. Mencapai komparabilitas mensyaratkan analis (1) mengidendifikasi perbedaan dasar dalam kebijakan dan prosedur akuntansi perusahaan, dan (2) menyesuaikan saldo untuk mencapai komparabilitas. Perbedaan dasar dalam akuntansi biasanya melibatkan salah satu bidang berikut

1. Penilaian persediaan (FIFO, biaya ratarata).

2. Metode penyusutan, terutama penggunaan penyusutan garis lurus versus di percepat.

3. Kapitalisasi versus pengeluaran biaya tertentu.

4. Kapitalisasi sewa versus non kapitalisasi.

5. Investasi pada saham biasa dilakukan dengan metode ekuitas versus nilai wajar.

6. Perlakuan berbeda dari biaya imbalan pascakerja.

7. Praktik yang dipertanyakan dalam mendefinisikan operasi dihentikan, penurunan nilai, dan pos tidak biasa.

Analisis harus menyadari bahwa sejumlah besar informasi yang penting tidak dimasukan dalam laporan keuangan perusahaan. Peristiwa yang melibatkan hal-hal seperti perubahan industri, perubahan manajemen, tindakan pesaing, perkembangan teknologi, tindakan pemerintah, dan aktivitas serikat kerja sangat penting bagi keberhasilan operasi perusahaan.

\section{METODE PENELITIAN}

Penelitian ini menggunakan deskriptif kuantitatif. Penelitian ini menjelaskan fenomena yang ada dengan mengunakan angka-angka dan dilaksanakan secara langsung ke sumber data, data yang dikumpulkan berupa data pendapatan perbulan selama 1 tahun, harga pokok produksi, dan data rincian biaya-biaya pada laundry 57. Penelitian ini menggunakan data primer, yaitu data asli yang dikumpulkan sendiri oleh peneliti dengan mengobervasi dan mewawancarai pemilik Laundry 57 untuk mendapatkan data terkait permasalahan dalam penelitian untuk mencapai tujuan dari penelitian ini. Data ini bersumber secara langsung dari Laundry 57 yang berlokasi di Jl. Tamalate 2, Mappala, Kec. Rappocini, Kota Makassar, Sulawesi Selatan.

Dalam penyusunan penelitian ini, peneliti mengumpulkan data dengan menggunakan metode observasi dan metode wawancara. Dalam metode observasi peneliti terjun langsung ke objek penelitian untuk mendapatkan informasi mengenai Margin Laba Bersih. Metode wawancara peneliti mengumpulkan data, pertanyaan yang dibutuhkan peneliti. Tujuan metode ini adalah untuk mendapatkan teori dan keterangan lain sebagai darsar pembahasan penelitian ini.

Dalam menganalisis data, penelitian ini menggunakan rumus Margin Laba Bersih yaitu sebagai berikut:

$$
\text { Margin Laba Bersih }=\frac{\text { Laba Bersih }}{\text { Penjualan Bersih }}
$$

\section{HASIL DAN PEMBAHASAN}

Berikut merupakan data pendapatan dan biaya laundry 57 pada tahun 2019.: 
Tabel 1 Pendapatan Usaha Laundry 57 Pada Tahun 2019

\begin{tabular}{cll}
\hline No. & \multicolumn{1}{c}{ Bulan } & Pendapatan \\
\hline 1. & Januari & Rp. 24.800 .000 \\
2. & Februari & Rp. 22.400 .000 \\
3. & Maret & Rp. 31.000 .000 \\
4. & April & Rp. 30.000 .000 \\
5. & Mei & Rp. 40.300 .000 \\
6. & Juni & Rp. 39.000 .000 \\
7. & Juli & Rp. 26.350 .000 \\
8. & Agustus & Rp. 26.350 .000 \\
9. & September & Rp. 27.000 .000 \\
10. & Oktober & Rp. 27.900 .000 \\
11. & November & Rp. 30.000 .000 \\
12. & Desember & Rp. 40.300 .000 \\
Jumlah & Rp. 365.400 .000 \\
\hline \multicolumn{2}{l}{ Sumber: Laundry 57} &
\end{tabular}

Tabel 2 Data Biaya-biaya Laundry 57 Pada Tahun 2019 (ribuan rupiah)

\begin{tabular}{|c|c|c|c|c|c|c|c|c|c|}
\hline No. & $\begin{array}{l}\text { Bu- } \\
\text { lan }\end{array}$ & $\begin{array}{l}\text { Deter- } \\
\text { jen }\end{array}$ & $\begin{array}{c}\text { Plas- } \\
\text { tik }\end{array}$ & $\begin{array}{l}\text { Par- } \\
\text { fum }\end{array}$ & $\begin{array}{l}\text { Lis- } \\
\text { trik }\end{array}$ & Air & $\begin{array}{l}\text { Gas } \\
\text { elpiji }\end{array}$ & $\begin{array}{c}\text { Gaji } \\
\text { karyaw } \\
\text { an }\end{array}$ & $\begin{array}{c}\text { Lain- } \\
\text { nya }\end{array}$ \\
\hline 1. & Jan & 325 & 520 & 170 & 1.000 & 500 & 1.080 & 3.000 & 130 \\
\hline 2. & Feb & 325 & 520 & 170 & 1.000 & 500 & 1.080 & 3.000 & 130 \\
\hline 3. & Mar & 365 & 560 & 340 & 1.000 & 500 & 1.620 & 3.000 & 130 \\
\hline 4. & Apr & 365 & 560 & 340 & 1.000 & 500 & 1.620 & 3.000 & 130 \\
\hline 5. & Mei & 375 & 600 & 340 & 1.000 & 500 & 1.620 & 3.000 & 130 \\
\hline 6. & Jun & 375 & 600 & 340 & 1.000 & 500 & 1.620 & 3.000 & 130 \\
\hline 7. & Jul & 365 & 560 & 340 & 1.000 & 500 & 1.620 & 3.000 & 130 \\
\hline 8. & Ags & 365 & 560 & 340 & 1.000 & 500. & 1.620 & 3.000 & 130 \\
\hline 9. & Sep & 365 & 560 & 340 & 1.000 & 500 & 1.620 & 3.000 & 130 \\
\hline 10. & Okt & 365 & 560 & 340 & 1.000 & 500 & 1.620 & 3.000 & 130 \\
\hline 11. & Nov & 375 & 600 & 340 & 1.000 & 500 & 1.620 & 3.000 & 130 \\
\hline 12. & Des & 375 & 600 & 340 & 1.000 & 500 & 1.620 & 3.000 & 130 \\
\hline \multirow{2}{*}{\multicolumn{2}{|c|}{ Jumlah }} & 4.340 & 6.800 & 3.740 & 12.000 & 6.000 & 18.360 & 36.000 & 1.560 \\
\hline & & \multicolumn{7}{|c|}{ TOTAL } & 88.800 \\
\hline
\end{tabular}

Sumber : laundry 57

\section{Perhitungan Net Profit Margin pada Laundry 57 tahun 2019}

Pada bulan januari Net Profit Margin Laundry 57 adalah sebesar $72,9 \%$ artinya, pendapatan sebesar Rp.1, usaha laundry 57 memperoleh laba bersih sebesar Rp.0,729. Bulan februari Net Profit Margin pada Laundry 57 mengalami penurunan sebesar $69,10 \%$ artinya, pendapatan sebesar Rp.1 usaha laundry 57 memperoleh laba bersih sebesar Rp.0,961 penerununan ini disebabkan menurunnya pendapatan. Mengalami kenaikan dikarenakan pendapatan dan biaya meningkat sehingga Net Profit Margin pada bulan maret sebesar $75,8 \%$ artinya, pendapatan sebesar Rp.1 memperoleh laba Rp.0,758. Dan pada 
bulan april Net Profit Margin laundry 57 mengalami penurunan lagi sebesar $74,10 \%$ artinya pendapatan sebesar Rp.1 memperoleh laba Rp.0,741 penurunan ini disebabkan penurunnya pendapatan. Bulan mei Net Profit Margin laundry 57 naik karena pendapatan dan biaya naik pada bulan sebelumnya menjadi $81,22 \%$ artinya, pendapatn sebesar Rp.1 memperoleh laba bersih Rp.0,8122. Di bulan juni NPM turun menjadi $80,6 \%$ atinya pendapatan sebesar Rp.1, usaha laundry 57 memperoleh laba bersih sebesar Rp.0,806 penurunan NMP pada bulan juni disebabkan menurunnya pendapatan dan biaya pun tetap.

NPM dibulan juli dan agustus pada Lundry 57 tetap mengalami penurunan dengan persentase rasio NPM yang sama yaitu sebesar $71,5 \%$ artinya pendapatan sebesar Rp.1 memperoleh laba bersih sebesar Rp.0,715 penurunan yang terjadi pada bulan juli dan agustus yaitu menurun drastisnya pada pendapatan dan pada biaya juga mengalami penurunan. Pada bulan september NPM laundry 57 naik menjadi $72,2 \%$ akbibat naiknya pendapatan dan biaya tetap seperti pada bulan sebelumnya, artinya pendapat sebesar Rp.1 memperoleh laba sebesar 0,722. Dan di bulan oktober NPM pada laundry 57 mengalami kenaikan pada bulan sebelumnya sehingga menjadi $73,1 \%$ artinya setiap Rp.1 pendapatan memperoleh laba bersih Rp. 0,731 kenaikan NMP ini disebabkan karena naiknya pendapatan dan tetapnya biaya. Bulan november NPM pada laundry 57 tetap meningkat menjadi $74,8 \%$ diakibatkan naiknya pendapatan dan biaya,artinya pendapatan sebesar Rp.1 memperoleh laba bersih sebesar Rp.0,748. Dan pada bulan desember 2019 NPM laundry 57 terus mengalami kenaikan dan besar NPM sebesar $81,2 \%$ artinya pendapatan sebesar Rp.1 memperoleh laba bersih sebesar Rp.0,812 kenaikan NPM yang terjadi secara terus-menerus hingga pada bulan desember 2019 ini diakibatkan naiknya pendapatan dan tetapnya biaya pada laundry 57.
Perkembangan Net Profit Margin Laundry 57 sangat baik yaitu berkisaran mulai dari $69,10 \%$ hingga $81,22 \%$, artinya kemampuan dalam memperoleh laba bersih pada laundry 57 secara keseluruhan sangat baik. Hasil dari perhitungan NPM atau Margin Laba Bersih dari usaha Laundry 57 memiliki persentase NPM berkisaran $69,10 \%$ hingga $81,22 \%$, hal ini memberikan sinyal baik bagi pemilik usaha Laundry 57 atas keuntungan yang diperoleh dari menjalankan usaha Laundry 57 pada tahun 2019. Serta dapat memperoleh sinyal informasi bagi pemilik usaha dari laba bersih yang diperoleh atas pendapatannya guna pencapaian peningkatkan keuntungan atau laba.

Pernyataan ini menyatakan bahwa perhitungan Margin Laba Bersih atau NPM sangat berpengaruh terhadap perhitungan keuntungan dan memberikan sinyal kepada pemilik usaha dalam memperoleh informasi atas operasi kegiatan Laundry 57 . Penelitian mengenai kajian margin laba bersih ini mendukung pernyataan dari sigarlaki et al (2014) dalam penelitiannya menyatakan bahwa net profit margin berpengaruh positif dan signifikan terhadap perhitungan laba bersih usaha depot air minum sam ratulangi. Dan memiliki pernyataan yang sama dengan penelitian yang dilakukan oleh Tompodung (2014) menyatakan bahwa Net Profit Margin berpengaruh dalam menilai kesuksesan usaha yang menjadi tolak ukur dalam mengetahui tingkat keuntungan atau laba yang diperoleh dari suatu bidang usaha.

\section{PENUTUP}

\section{Kesimpulan}

1. Net Profit Margin pada Laundry 57 sangat baik yaitu berkisaran $69,10 \%$ $81,22 \%$ dan mengalami trend kenaikan pada tahun 2019.

2. Bulan januari sampai bulan juni tahun 2019 Net Profit Margin laundry 57 
mengalami naik turunnya NPM, disebabkan adanya penaikkan dan penurunan pada pendapatan dan kenaikan pada biaya-biaya laundry 57 , NPM nya yaitu sebesar $72,9 \%$, $69,10 \%, 75,8 \%, 74,10 \%, 81,22 \%$ dan $80,6 \%$

3. Pada bulan juli dan bulan agustus tahun 2019 NPM pada laundry 57 mengalami penurunan dari bulan sebelumnya dengan persentase rasio NPM yang sama yaitu sebesar $71,5 \%$ dikarenakan karena naik turunnya pendapan dan biaya pada laundry 57.

4. Dan Net Profit Margin laundry 57 pada bulan september hingga bulan desember tahun 2019 mengalami kenaikan secara terus-menerus di akibatkan naiknya pendapatan dan biaya pada laundry 57. Dengan besarnya rasio NMP yaitu: $72,2 \%$, $73,1 \%, 74,8 \%$, dan $81,2 \%$.

\section{Saran}

1. Mengingat trend kenaikan pada Net Profit Margin Laundry 57 maka harus dipertahankan dan selalu memperhatikan pendapatan dan biayabiaya yang dikeluarkan pada laundry 57.

2. Pada bulan januari sampai bulan juni agar selalu memperhatikan pendapatan dan biaya agar NPM usaha jasa laundry 57 selalu dalam keadaan stabil seperti bulan sebelumnya.

3. Net Profit Margin laundry 57 pada bulan juli dan bulan agustus 2019 perlu ditingkatkan lagi agar tidak mengalami penurunan pada NPM.

4. Di bulan september sampai pada bulan desember 2019 Net Profit Margin pada laundry 57 perlu dipertahankan atau perlu di tingkatkan untuk lebih baik lagi ke periode berikutnya.

\section{REFERENCES:}

Hasanuddin. 2019. Analisis Kualitas Auditor, Leverage, Dan Persentase Saham Initial Public Offering Terhadap Earnings Management Perusahaan Go Public. Jurnal IImiah Akuntansi Universitas Pamulang. 7(2).

Hasanuddin. 2018. The Influence of Good Corporate Governance, And Quality Of Audit Against The Integrity Of The Financial Statements. International Journal Economics, Management and Social Science, 1(3).

Hasanuddin. 2017. The Influence of the Competence of Auditors and Auditors Independence Could Affect the Integrity of the Financial Statements. Jurnal Aplikasi Manajemen, Ekonomi, dan Bisnis STIM Lasharan, 2(1).

Hery.2016. Analisis Laporan Keuangan. Jakarta: PT Grasindo.

Kieso, Donald et al. 2018. Akuntansi Keuangan Menengah Intermediate Accounting. Jakarta: Salemba Empat.

Lubis, Hidayat Rahmat. 2017. Cara Mudah Menyusun Laporan Keuangan Perusahaan Jasa. Yogyakarta: C.V Andi Ofset.

Prihadi, Toto. 2019. Analisis Laporan Keuangan. Jakarta: PT. Gramedia

Prihadi, Toto.2013. Analisis Laporan Keuangan. Jakarta: PPM

Sugiono, Arief dan Edi Untung. 2016. Panduan Praktis dasar analisis laporan keuangan. Jakarta: PT. Grasindo.

Sunyoto, Danang. 2013. Metode Penelitian Akuntansi. Yogyakarta: PT. Refika Aditama.

Tompodung, Osin. 2013. Analisis Net Profit Margin Pada Usaha Laundry Di Kota Manado. Jurnal EMBA, 2(2),19. 